\title{
POST-INDEPENDENCE BASIC EDUCATION IN KENYA: AN HISTORICAL ANALYSIS OF CURRICULUM REFORMS
}

\author{
Justus O. Inyega \\ University of Nairobi, Kenya \\ Adeela Arshad-Ayaz ${ }^{1}$ \\ Concordia University, Canada \\ M. Ayaz Naseem \\ Concordia University, Canada \\ Evans W. Mahaya \\ University of Nairobi, Kenya \\ Dalia Elsayed \\ Concordia University, Canada
}

\begin{abstract}
This article presents a critical review of the education system and curriculum reforms in basic education in Kenya from independence in 1963 to date. It presents a philosophical and pragmatic basis for content review and the curriculum reform process. Data collection involved a critical review of relevant literature; including several curriculum reform documents. Based on the literature review and documentary analysis, there is overwhelming evidence that radical changes have resulted in the Kenyan education system from several curriculum reviews and major reforms in response to the changing needs of the Kenyan society. The new curriculum currently under implementation is the Competency-Based Curriculum (CBC). Over the years, there have been minimal changes in the content, scope, and sequence of the basic education curriculum. This article presents salient changes in the Kenyan education system and presents recommendations that may have significant implications for future curriculum reforms that can potentially improve learning outcomes.
\end{abstract}

Keywords: curriculum reform, basic education, competency-based curriculum, historical analysis.

1 Correspondence: 1455 deMaisonneuve Blvd. West Montreal, Quebec, H3G 1M8 Canada; Adeela.ayaz@gmail.com 


\section{Introduction}

The current basic education school curriculum in Kenya is undergoing a reform. Existing literature suggests that the current 8-4-4 curriculum is theoretical and does not focus on the development of learners' competencies and skills (Jepkemei, 2017; Njeng' ere, \& Lili, 2017; Ogutu, 2017; Kaviti, 2018; Wanjohi, 2018). The literature alludes to current pedagogical practices as authoritarian, rigid, and teacher-centered (Jepkemei, 2017). Consequently, learning activities are often limited to rote memorization of facts and reciting them to the teacher or regurgitating the knowledge during examinations (Jepkemei, 2017).

In the context of learner assessment practices, the existing literature is critical of the over-emphasis on examinations (Jepkemei, 2017; Waiganjo, 2017). At the same time, scholars are generally appreciative of the use of the mother tongue as the language of instruction (Bamgbose, 2005; Piper, Trudell \& Shroeder, 2015). Some schools start learners on English and Kiswahili much earlier in their formative years of school. The curriculum review and education reform process in Kenya epitomizes the government's commitment to improving learning outcomes. Scholars have argued that the new Competency-Based Curriculum (CBC) is likely to benefit learners in a variety of ways. Whether or not the Competency-Based Curriculum reform process will address a myriad of systemic problems bedeviling the education sector is a matter that is yet to be determined.

This article presents a critical review of the education system and curriculum reforms in basic education in Kenya from independence in 1963 to date and makes important recommendations for future curriculum reforms that can be instrumental in improving learning outcomes. Employing critical document analysis as the methodological orientation, the paper analyzes an exhaustive corpus of education acts, commission reports, documents from the Ministry of Education, Science, and Technology, and Kenya National Examination Council assessment reports ${ }^{2}$. The paper is organized into five sections. In the first section, the paper presents a brief overview of the gaps in the literature on the status of basic education in Kenya. In the second section, the discussion focuses on the rationale for the current curriculum reform in Kenya. The third section is devoted to an exposé of the organization of basic education in the new curriculum with special emphasis on early and middle school education along with a discussion of learners with special educational needs. In the fourth section, the paper examines the assessment approaches, especially the competency-based assessment, summative assessment, and assessment as learning. Discussion and future directions are presented in section five, followed by the concluding section and recommendations.

\section{Identifying Gaps in scholarship on the Status of Basic Education in Kenya}

At face value, the status of Kenya's basic education seems to have improved over the years. However, a closer look paints a mixed picture, with qualitative weaknesses masking whatever quantitative gains have been made thus far. Research from diverse sources consistently shows very low early grade reading and numeracy outcomes in both formal and non-formal settings (PAL Network, 2020; Piper \& Zuilkowski, 2015; Uwezo, 2016), across

2 Legal instruments analyzed include: Kenya Education Commission - Ominde Commission (the Republic of Kenya, 1964, Republic of Kenya, 1965a, Republic of Kenya, 1965b); The National Committee on Educational Objectives and Policy - Gachathi Report (Republic of Kenya1976), The Presidential Working Party on the Second University - Mackay Report (Republic of Kenya, 1981a), The Presidential Working Party on Education and Manpower -Kamunge Report (Republic of Kenya, 1988); Commission of Inquiry into the Education system of Kenya- Koech Commission (Republic of Kenya, 1999); The 2012 Odhiambo Task Force on the Re-alignment of the Education Sector to the Constitution of Kenya 2010; Vision 2030 and National Curriculum Policy (2015). 
urban and rural locales (NASMLA, 2010), and in mother tongue learning (Piper et al., 2015), in Kiswahili and English (Piper \& Zuilkowski, 2015). This is compounded further by obsolete pedagogical strategies and methods; high levels of both teacher and student absenteeism; inadequate infrastructure; shortage of instructional materials; uneven distribution of teachers; low levels of accountability; and resource misallocation; incomplete or even deliberately falsified school data and regional disparities (Uwezo, 2015; World Bank, 2018); all of which have adverse effects on learning outcomes. Foundational learning is particularly resonant amidst natural and man-made disasters (such as the COVID-19 crisis), as foundational skills are the easiest to lose when schooling is interrupted and are also the hardest to regain once schooling re-starts.

As far back as 2005, many Kenyan children were not reaching the intended benchmarks (Onsomu et al., 2005). According to Onsomu et al., just $21 \%$ of $6^{\text {th }}$-graders had a 'desirable level' of reading, indicating the ability to handle the reading requirements of the following academic year. The percentage of learners achieving the minimum threshold in mastery actually decreased between 1998 and 2000. Learning outcomes have not shown significant improvement in more recent surveys (e.g., PAL Network, 2020; Uwezo, 2015; 2016).

In 2013, Uwezo assessed more than 325,000 children aged six to 16 in just under 150,000 households in 366 districts and over 10,000 public primary schools in Kenya, Mainland Tanzania, and Uganda through tests set at the 2nd-grade level. In Kenya, 64\% passed the literacy and numeracy test, while less than seven out of 10 children aged 10-16 have mastered standard two literacy and numeracy skills. In essence, Kenya along with Uganda and Tanzania, missed the target of ensuring that all children have access to quality learning.

Uwezo (2015) emphasized that the success of action taken to improve the education sector should be measured by improved learning outcomes. Results have to be directly useful, transparent, and easy for teachers to inform their instruction and underpin communication with parents and communities and those who supervise the teachers. Learning outcomes has to be the driving concern and energy expended on what works. The buck seems to stop on what happens in the classroom and begs the question: Are our children learning?

Answers to this question will be inconsistent if one does not take a critical look at the curriculum based on the assumption that it provides guidance on how to modify the structure, content, and policy framework for improved basic education service delivery.

To address this, Education Evidence for Action (EE4A) ${ }^{3}$ targeted and brought together senior Ministry of Education personnel to conferences in 2015, 2017, and 20194 in a proactive strategy to link education evidence to policy and action. These policy forums have contributed immensely to education reforms and, in particular, implementation of the Competency-Based Curriculum (CBC) policy and practice. The emphasis in the $\mathrm{CBC}$ on literacy and numeracy, for instance, is a direct outgrowth of the learned forums. Secondly and equally important, the move away from an emphasis on summative evaluations towards competency-based assessments (such as KEYA ${ }^{5}$ ) is informed by UWEZO and similar studies (e.g., PAL Network, 2020) undertaken in Kenya. Significantly, the 2019 conference answered three interrelated questions: Are all children learning? What is the potential of the $\mathrm{CBC}$, as

3 A coalition of civil society organizations (led by Twaweza East Africa responsible for UWEZO studies and Research Triangle Institute (RTI) International of the cited Piper et al studies) and academia.

4 https://www.poverty-action.org/event/education-evidence-action-ee4a-conference-2019

5 KEYA stands for Kenya Early Years Assessment (KEYA) see https://kenyayote.com/how-to-register-forgrade-3-keya-exams-knec-enrollment-procedure/ 
envisaged, to remedy the gaps in learning outcomes? What opportunities exist for the continued enrichment of the curriculum implementation process to realize its full potential?

In sum, Uwezo studies, analyzed collectively with other data sources, have helped the MoE to identify critical learning gaps in basic education, understand reasons for insufficient learning, and provided robust intervention models and corrective measures to deal with it sustainably, cost-effectively, and early in children's schooling trajectory. Stated differently, EE4A has gone beyond sensitizing $\mathrm{MoE}$ on learning gaps to catalyzing action towards quality education and improvement of learning outcomes. MoE has leveraged EE4A findings to target interventions in low-performing counties and marginalized communities towards the achievement of inclusive and equitable quality education and lifelong learning opportunities for all.

\section{The Rationale for Current Curriculum Reform}

Since the introduction of the Western system of education in the 1800 s, the question of relevance has been one of Kenya's preoccupations (Amukowa et al., 2013; Mackatiani et al., 2016). According to Amukowa et al. (2013) and Jepkemei (2017), concerted efforts in education reforms are in response to Kenya's social and economic needs and to align education to international and local legal instruments such as the Universal Declaration on Human Right (1948); the International protocol that established Education for All (EFA) agenda in Jomtien, Thailand in 1990; the World Education Forum (WEF) in Dakar, Senegal in 2000; and Sustainable Development Goals (SDGs) in September 2015. These documents collectively provide for the right to an inclusive and equitable quality education and lifelong learning opportunities for all for sustainable development. Local legal instruments (Acts, Commissions, Committees, Taskforces, and sessional papers) that have informed education reforms include the Ominde Commission (1964) and Mackay Report (1981).

The Ominde ${ }^{6}$ Commission (1964) was the first Commission after independence in 1963. Its objective was to introduce a single educational system to promote national unity and inculcate learners' desire to serve their Nation (Simiyu, 2001). The Commission supported the government's initiative to abolish racial segregation in schools and urged them to offer bursaries to African children so that they could join schools dominated by Europeans and Asians. The Commission recommended setting up six clear broad goals of education: national unity, national development; individual development and self-fulfillment; social equality; respect and development of cultural heritage; and international consciousness. These goals guide the education system to date.

The Ominde Commission (1964) recommended free universal primary education (Mackatiani et al., 2016) and a curriculum that was 'Kenyan'. Changes were duly made in the history and geography subject content to reflect this reality. Kiswahili was made a compulsory subject in primary and secondary school. English was to be the medium of instruction from Grade One. Religious education became a subject with an aim not to proselytize children. Religious bodies were to fund schools and offer pastoral care. The National Anthem was to be sung in school and the flag raised. This is done to date.

The Ominde Commission (1964) recommended the establishment of the East African Examinations Board to replace the Cambridge University Local Examinations Syndicate to ensure that curriculum change was reflected in examinations; creation of national schools and encouraging all government-maintained secondary schools to have 20 percent of their students from other parts of the country; an affirmative action that is still upheld today.

6 Named after its chairperson Professor Simeon H. Ominde, then Minister of Education. 
Teachers were to work anywhere in the country to develop a national outlook, a deployment practice upheld to date.

The Ominde Commission (1964) recommended creating the Kenya Institute of Education (Now Kenya Institute of Curriculum Development). It recommended a 7-4-2-3 system of education: seven years of uninterrupted primary education, four years of secondary education, two years of advanced secondary education, and a minimum of three years of university education. It recommended Government regulation of Harambee schools ${ }^{7}$ (to curb unemployment and frustration of its graduates), inclusion in educational planning, and availing them professional advice (Mackatiani et al., 2016). The 1964 constitution made the government responsible for all sectors of education.

The Ominde Commission (1964) advocated for the development of adult education to enable people with elementary education to participate in national and economic development. The Commission recommended in-service training for primary school teachers and general planning of education to be centralized while administration and management of primary schools would be done by school committees and Parent-Teacher Associations and secondary schools and other tertiary institutions by Boards of Governors; a practice that exists to date.

The government responded positively to the Ominde Report. It affected reforms, including the establishment of non-racial schools. Former European schools were given local names. For instance, Duke of York became Lenana School, and Duchess of Gloucester became Pangani Girls Secondary School. African students were given bursaries to join high cost Asian and European schools. By 1966, the African population in these schools was 30 percent. The population increased to 65 percent in 1969 and almost 100 percent in 1970.

After the establishment of KIE, a common syllabus and common examination were introduced in 1966. Kenya Preliminary Examination was replaced by Certificate of Primary Education. East African Examinations Council was established in 1967 to administer the East Africa Certificate of Education (which replaced the Cambridge School Certificate) and the East Africa Advanced Certificate of Education (which replaced the Cambridge Advanced School Certificate examination). Kenya Junior Secondary Examination was introduced in 1966 to be administered at the end of Form Two ( $9^{\text {th }}$ Grade) to enable students in 'Harambee' schools to join government schools or terminate their education and join the labor market. The government took over some of the 'Harambee' schools by 1969 and posted qualified teachers there.

Between 1964 and 1985, the 7-4-2-3-system was operational: seven years of primary, four years of lower secondary (Form 1-4), two years of upper secondary (Form 5-6), and a minimum of three years of university education - this excluded pre-primary education, which has now been addressed in the new curriculum.

Over time the 7-4-2-3 system of education, recommended by the Ominde Commission, and once regarded as a medium for social mobility and national economic development, was criticized for its lack of capacity and flexibility to respond to changing aspirations of Kenyans and labor market needs (Owino, 1997); According to Owino, call for reforms was widespread and based on the perceived weakness of existing educational policy as being too academic and encouraging elitist and individualistic attitudes among school leavers (Simiyu, 2001); lacking in orientation to employment and, therefore, not suitable for direct employment.

7 These were schools set up by communities by pooling their resources in the spirit of Harambee - "let us pull together". The schools experienced rapid growth at independence to meet the demand for secondary school education. Unfortunately, many of these schools were unregistered and lacked basic facilities and qualified staff, and generally admitted students who may not have performed very well at the end of primary education. 
In the 1980s, the government was forced to change its policy on education. The philosophical underpinnings and rationale for the policy change and attendant curricula review stemmed from the difficulties faced by graduates at both primary and secondary levels for they could not be absorbed into the shrinking labor market. The government set up a Presidential Working Party on the Second Kenyan University in 1981 (the Republic of Kenya, 1981a), in what became the Mackay Commission (1981).

The Mackay Commission (1981) investigated how graduates at each education cycle could be self-sufficient and productive in agriculture, industry, and commerce through technical, scientific, and practical knowledge and lifelong skills. They proposed 8-4-4.8 system of education to orient youths towards self-employment (King \& McGrath, 2002) through attitudinal and skills preparations for the world of work. Mackay advocated for a practical curriculum that would offer a wide range of employment opportunities and equitable distribution of educational resources. Mackay recommended the establishment of a second university (Moi University) with faculties of technology, agriculture, commerce, education, science, veterinary medicine, information sciences, forestry resources and wildlife management, health sciences; social, cultural and development studies; school of graduate studies; school of environmental studies and the institute of applied science and technology and cost-sharing in university education.

The conception of the 8-4-4 system of education in January 1985, it's planning, launching and implementation was against the backdrop of Structural Adjustment Programmes (SAPs), initiated by the World Bank and the International Monetary Fund and donor fatigue, which ignited a series of economic and political reforms that impacted negatively on educational progress in Kenya. The education sector experienced two major shocks: the cost of implementing the 8-4-4 system of education and the cost-sharing policy, which led to a sharp increase in the cost of attending school and triggered a massive decline in primary school enrolments.

Vocational education was the linchpin of the 8-4-4 system of education. The need to provide pre-vocational and technical education increased the cost of attending primary school by more than 100 percent. It increased pressure on existing learning facilities, including workshops and home-science classrooms. The financial responsibility to provide those facilities was placed on parents, school committees, and the local community served by the school. The burden to provide new textbooks also increased. The new system also increased the burden on teachers and students with limited learning facilities. The system became burdensome to students who had to spend more time in school. Most teachers were not adequately trained to teach some of the vocational and pre-technical subjects. Later on, the 8-4-4 education system was criticized for being broad, expensive, and burdensome to pupils and parents. Amutabi (2003a, p.136) notes that:

The 8-4-4 system of education introduced in 1985 remains the most radical and perhaps mindless change in education in Kenya since independence. It has already caused great devastation to Kenya that even if it were changed today, the toll on the Nation will be felt for many years to come. Its devastation is similar to that of the failed Ujamaa in Tanzania many years after it was officially scrapped.

8 8-4-4: Eight years of primary education, four years of secondary education, and four years of basic university education. Mackay report recommended scrapping of A-levels and simultaneously added an extra year each to primary and university education, respectively. 
Some Kenyan elites opposed to the 8-4-4 educational system claimed the change was not educational but politically instigated and that there was no crisis in the old system to warrant the change. In response to criticisms such as these, other commissions were formed to improve the 8-4-4 system that ultimately ushered in current curriculum reforms.

In 2018, the Ministry of Education announced that from 2020 the country would implement Competency-Based Education. The announcement evoked mixed reactions because, unlike previous curricula changes that were always preceded by education inquiry, this one seems to have not. To date, there has been no authoritative statement from the government about the new system.

\section{Figure 1:}

Organization of Basic Education

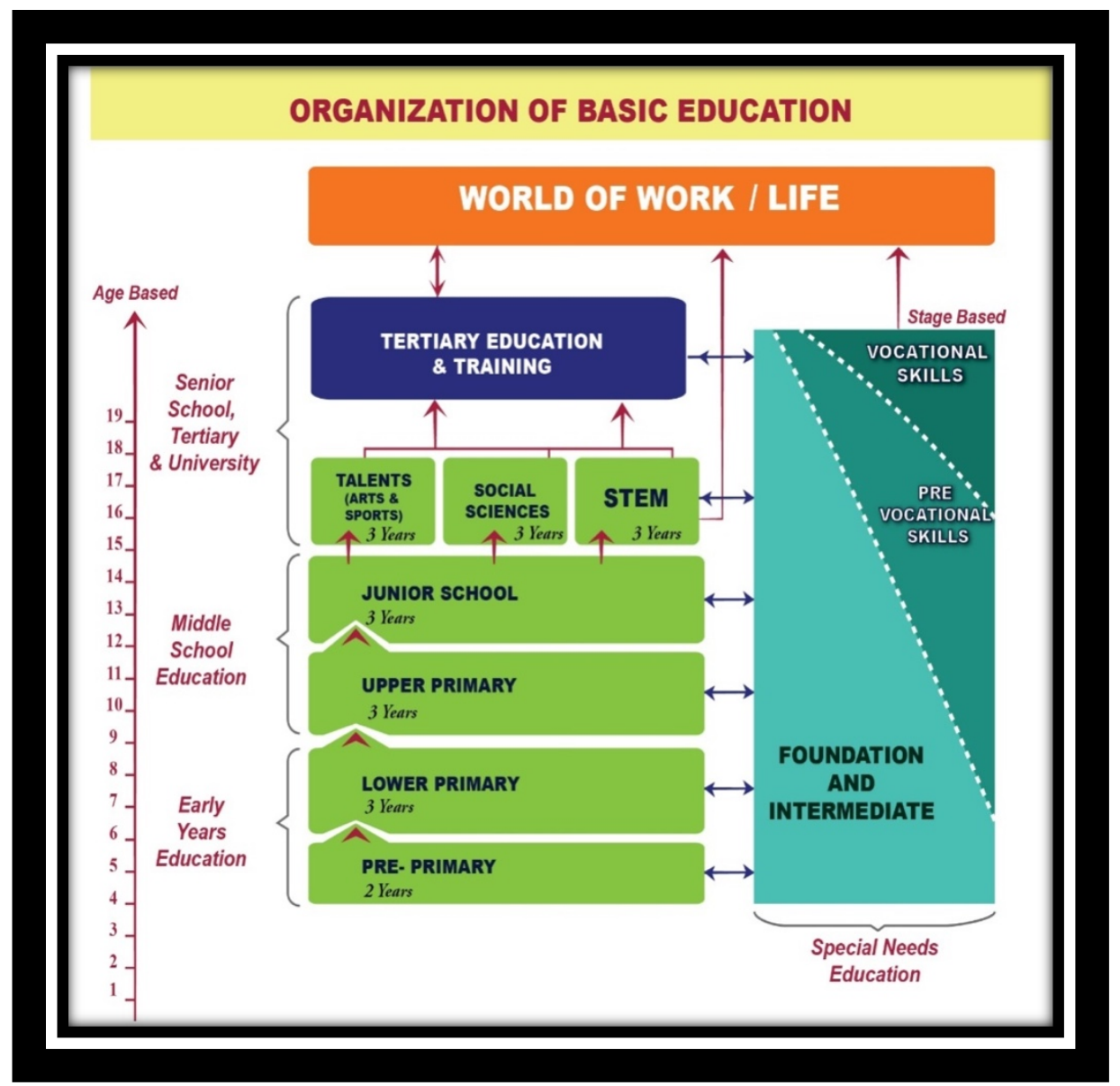

Source: (Kenya Institute of Curriculum Development [KICD], 2017a).

The general consensus, however, is that review of the 32-year old 8-4-4 system had long been overdue. It needed to be aligned with Constitution (2010), which guarantees the right to free and compulsory basic education as a human right to every Kenyan child; and Kenya Vision 2030, which singles out education and training as the main vehicles that will propel Kenya into a middle-income economy. The curriculum also needed to be aligned with the Basic Education Act 2013, KICD Act 2013, and NESSP 2019 to ensure a seamless

9 NESSP is the National Education Sector Strategic Plan (2019) informing education in 2018 -2022. 
transition of all children from one level to the next through the creation of different pathways. The curriculum needed to amplify the benefits of vocational and technical subjects.

On another trajectory, there have been increases in violence, including inter-ethnic clashes, the radicalization of youth, and terrorism. Curricular reform is needed to address these and other emerging challenges facing youth today. The education system also needed to keep abreast of the pace of ICTs and globalization and to look at education as a course of life and not merely as a course of study. Such an approach shifts focus on critical skills, including literacy, numeracy, life skills, and how learning can be made meaningful across disciplines and concomitant focus on $21^{\text {st }}$-century skills such as critical, creative, logical, and rational thinking, problem-solving, communication, and innovativeness.

There was a need to move away from the emphasis on summative evaluation with its implications on the psychosocial being of Kenyan children (Jepkemei, 2017; Waiganjo, 2017). Regional trends and push for international benchmarking and harmonization of curricula were overwhelming, especially when the policy framework for such a move had been accomplished within East African partner states. Then the government, developed regional curriculum standards to harmonize the Kenya National Qualifications Framework with those of the East African Community. Under the auspices of UNESCO, Kenya has aligned the curriculum to the International Bureau of Education (IBE) to benchmark with other international curriculum development centers. Lastly, KICD has come up with the Basic Education Curriculum Framework (BECF), which outlines how basic education will be organized (see Figure 1).

From Figure 1, basic education will be organized into three levels: Early Years Education, Middle School Education, and Senior School Education.

\section{Early Years Education}

Early Years Education will consist of two years of pre-primary and three years of lower primary education. The subjects, now called learning areas, in pre-primary education include language, mathematics, environmental, psychomotor and creative, and religious education activities. Learners will also undertake community service learning.

Assessment will be formative, learner-centered, and highlight a child's progress over time. It will cover cognitive, psychomotor, and affective domains. It will be based on developmental milestones and determined through observation of activities and oral questioning. Data gathered will be used to plan experiences to bolster and enhance the individual child's development, not for comparison with others.

Learners will move to lower primary for three years. Their learning areas will include literacy, Kiswahili language activities or Kenyan Sign Language for the hearing impaired, English language activities, indigenous language activities, mathematical activities (for dayto-day living), environmental activities (science, social, and agriculture), hygiene and nutrition activities, religious education and life skills activities, and creative activities. ICT will be an integral learning tool at this level.

Assessment for learning from Grades 1-3 will be continuous through portfolios. Transition to Grade 4 will be determined by a national assessment administered at Grade 3. The assessment will not be individualized; rather, it will give an overall picture of whether learners have acquired expected competencies. To avoid doctoring of assessment, learners will thus be randomly sampled.

\section{Middle School Education}

Middle School Education will include three years of upper primary and three years of 
junior secondary education. Upper primary, a three-year program (grades 4-6), will expose learners to a broad curriculum with opportunities for exploration and experimentation. The learning areas will include English, Kiswahili, or Kenyan Sign Language for the hearing impaired, home science, agriculture, science and technology, mathematics, religious life skills education, creative arts, physical and health education, and social studies. Foreign languages will be optional. ICT will remain integral at this level as well. Assessment for upper-primary will be continuous through learners' portfolios, and transition to Grade 7 will be via national assessment administered at Grade 6 to a random sample of learners.

Lower secondary will last three years (grades 7-9). By this time, learners will already have been introduced to optional subjects offered in $7^{\text {th }}$ grade so they can make informed choices. The curriculum in the lower secondary will be broad-based to enable learners to explore their abilities, personality, and potential. The learners will also undergo a rigorous career guidance program to enable them to make informed subject choices. Learners will take 12 core subjects and choose one or two optional subjects based on their personality, abilities, interests, and career aspirations. ICT will be a delivery tool for all learning areas.

Schools will liaise with colleagues, local stakeholders, and the business community for 'on the job' opportunities for learners to apply school-based learning in a range of real-life activities. Formative evaluation, forming $70 \%$ of the final grade at the end of the lower secondary, will be carried out throughout the course. The remaining $30 \%$ will be from a national examination administered by the Kenya National Examination Council, informing the selection of different pathways and tracks.

\section{Senior School Education}

Senior School Education (SSE), a three-year course (Grades 10-12), will target learners around 15 to 17 years of age. SSE will lay the foundation for further education and training at the tertiary level. Learners in SSE will have explored their interests and potential career paths at lower secondary. This will enable them to choose one of three pathways: Arts and Sports Science, Social Sciences, or Science, Technical, Engineering, and Mathematics. Various tracks are available within each pathway; schools can decide to offer one or more tracks in a pathway. Whichever pathway they choose, all SSE learners will have to complete: Community Service Learning and Physical Education. Community Service Learning integrates classroom learning and community service to enable learners to reflect, experience, and learn from the community. Learners will carry out at least 135 hours of community service outside of classroom time over the course of their three years in SSE.

The idea of pathways has repeatedly been recommended in government documents to help Kenya achieve aspirations of Vision 2030. NESSP (2019) recognizes that learners have unique competencies and a range of skills, interests, experiences, and aspirations that can only be harnessed by providing learning pathways. Providing learners with an education that takes them down relevant pathways will facilitate their development and self-fulfillment, equipping them with practical skills for employment or help them move into selfemployment. Other countries such as Canada ${ }^{10}$, Malaysia ${ }^{11}$, New Zealand ${ }^{12}$, and Germany ${ }^{13}$

10 Pathways to Education. (2016). Program Results. [online] Available at: https://www.pathwaystoeducation.ca/programresults [Accessed 24 Nov. 2016].

11 StudyMalaysia.com (2016). A Glance at The Malaysian Education System - StudyMalaysia.com. [online] StudyMalaysia.com. Available at: https://studymalaysia.com/international/the-national-education-system/a-glance-at-themalaysian-education-system [Accessed 24 Nov. 2016].

12 Edgazette.govt.nz. (2016). Building strong foundations, clear pathways, successful transitions. [online] Available at: http://www.edgazette.govt.nz/Articles/Article.aspx?ArticleId=8790 [Accessed 24 Nov. 2016].

13 Bonn 2015 Secretariat of the Standing Conference of Ministers of Education and Cultural Affairs of the Lander. 
(Bonn, 2015) have already adopted similar approaches at the secondary level.

Learners' knowledge will be assessed based on the information retained, understood, and applied in addition to their ability to evaluate information and create knowledge. Assessment will take place over a period of time using projects, journaling, profiles, and portfolios involving parents and other stakeholders. Learners' overall assessment at the end of SSE will be based on project work, a national examination, and community service learning. If community service learning is not completed, a learner will be denied secondary certificates and entry to tertiary education. The curricular reform lays special emphasis on learners with special needs, an area that was not especially focused on in the previous reforms.

\section{Learners with Special Educational Needs}

Learners with special needs, like all young people, have potential that needs to be nurtured. The model in Figure 2 has been designed to enable learners with special needs to feel included in the educational system and be a part of the Kenyan society and workforce.

\section{Figure 2:}

Special Needs Education Curriculum Model

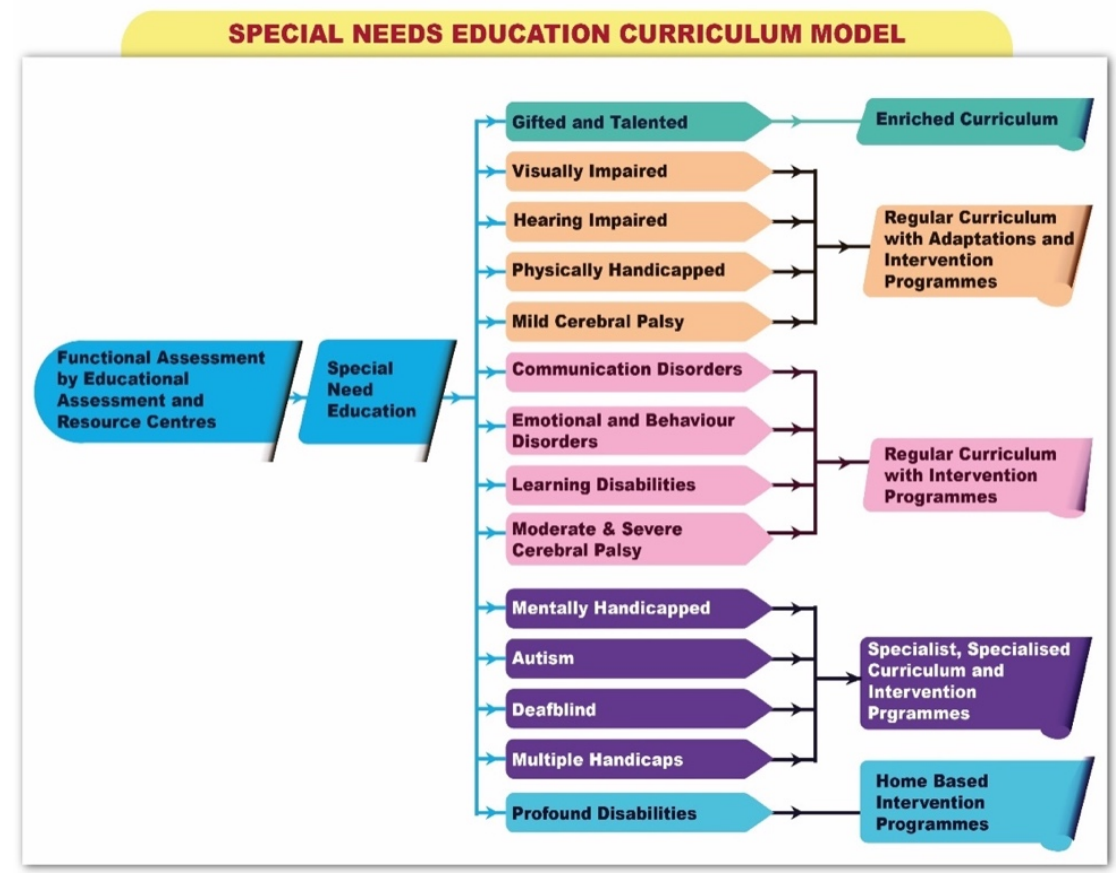

Source: (Kenya Institute of Curriculum Development [KICD], 2017b).

Education of learners with special needs starts with a functional assessment to determine whether the learner should be placed in a special school, special unit, regular school, or in a home-based program and the type of intervention that will be suitable. Some learners with special needs will follow the regular curriculum with adaptations to content, teaching, and learning strategies in addition to resources and assessment. These learners include those with visual impairment, hearing impairment, physical disability, mild cerebral palsy, learning disabilities, emotional and behavioral difficulties, and communication disorders. For gifted and talented learners, the curriculum will be enriched through 
additional and advanced content and resources.

Other learners with special needs may not follow the regular curriculum, including those with mental disabilities, deaf-blindness, autism, cerebral palsy, multiple disabilities, and profound disabilities. The primary purpose of education for these learners is to enable them to live an independent life. Their curriculum will be stage-based, not age-based. They will study at four levels of education, with transition dependent on the demonstration of outcomes. The first is the foundation level in which learning outcomes are appropriate communication, pre-numeracy, pre-literacy skills, spiritual and social skills, independent living skills, exploring the environment for learning, and applying digital literacy skills. Following the foundation level, learners' transition to the intermediate level. Here they will focus on the same learning outcomes but at a higher level. Learners with special needs who are exceptionally talented in specific areas may require a syllabus that is geared towards nurturing and developing their talents. Following the intermediate level, learners' transition to the pre-vocational level.

At the pre-vocational level, learners are introduced to the preliminaries of many skillsbased fields and are given the opportunity to identify their abilities and interests. Learning includes skills in areas such as weaving, animal husbandry, cookery, hairdressing and beauty, dressmaking, carpentry, metalwork, building construction, and horticultural farming. Learners also focus on homemaking skills, and digital literacy is integrated across learning areas. Once a learner's abilities and interests have been identified at the pre-vocational level, they will be placed in a given field. A home-based program has been designed for learners with profound disabilities who are mostly at home and may benefit from the services of EARC officers and other auxiliary services.

\section{Assessment Approaches in Basic Education}

Education assessment is the process of determining the extent to which learners have acquired knowledge, skills, values, attitudes, and abilities that have been specified (predetermined) before a course begins. The assessment information is useful for monitoring learners' progress, providing feedback, informing the next steps in learning, and guiding future courses. Assessment can be at the classroom or national level. Several methods are used to collect and record information about a learner's progress in all subjects. Assessment is often overlooked when planning and implementing curricula change. However, in current curricula reform processes, assessment is integral. Specifically, four types of assessment will inform students' progress and achievement in basic education.

\section{Competency-Based Assessment}

Competency-based assessment (CBA) involves determining a learner's capability to apply knowledge, skills, and abilities to successfully perform tasks in a defined setting (UNESCO IBE, 2013). The process starts with a personal assessment against a set of competencies - the assessor uses evidence to judge whether an individual is competent. Evidence may be direct, such as observation of performance, and indirect, such as formal testing and testimonies from others. The assessor reviews this evidence and verifies it with the person performing the skill. The assessment must be valid, reliable, flexible, and fair. Learners are considered competent when they are able to consistently apply their knowledge and skills to the standard of performance required in the school. CBA foregrounded in current reform processes is a radical shift and departure from current assessment practices of comparing learners with each other (norm-referenced assessment) towards assessment practices that collect evidence and make judgments on the extent and nature of the progress 
of each learner.

\section{Formative Assessment (Assessment for Learning)}

Formative assessment is carried out during curriculum instruction to monitor learning. It provides ongoing feedback for teachers to improve their teaching and students to improve their learning (Bennet, 2011; Province of Manitoba, 2006) towards desired outcomes. Information from formative assessments can help close the gap between current and desired achievement levels (Dunn and Mulvenon, 2009).

The formative assessment uses both formal and informal methods to monitor a learner's progress and collect information on their ability to demonstrate competencies (Looney, 2011). Formative assessments also focus on other abilities, attitudes, and aptitudes to assess a learner's development across all areas of learning. Current reforms mandate that assessments are made on recorded evidence (portfolios) maintained by the class and/or subject teacher.

\section{Summative Assessment (Assessment of Learning)}

Summative assessment evaluates student learning, skill acquisition, and academic achievement at the end of a defined instructional period (Looney, 2011), or learning has been completed (Province of Manitoba, 2006). Assessment information and feedback sum up the teaching and learning process. It is a synoptic assessment of learning outcomes, in which students demonstrate their ability to integrate and apply skills, knowledge, and understanding across the breadth and depth of the subject. Individuals are compared against a standard or benchmark, and the result is used for placement, certification, ranking, or grading of learners and for deciding on progression to the next level of education.

By assessing a learner's capability to apply knowledge and skills gained in one part of the course to other parts of the course, or across the course as a whole, summative assessment enhances the links between different parts of a syllabus and reduces compartmentalization of learning. In the new curriculum, summative assessment will be at the end of Early Years Education, Middle School Education, and after Senior School Education.

\section{Assessment as Learning}

Assessment as learning uses assessment to develop and support learners' metacognition (Province of Manitoba, 2006). It focuses on the student's role as the critical connector between assessment and learning, with an emphasis on fostering skills and habits such as self-assessment, self-monitoring, and self-correction. Teachers may refer learners to their personal goals or external standards as references for self-assessment. They may also facilitate self-assessment among students by introducing the use of self-reflection questions and exemplary work for consideration. Assessment as learning promotes students' awareness of strengths and weaknesses in their learning (Looney, 2011). In the new curriculum assessment as learning is prioritized to promote learning to learn; critical thinking and problem-solving; imagination and creativity; and self-efficacy skills in learners.

Assessment as, for, and of learning mainstreamed in the new curriculum is the gamechanger needed to catalyze further education reform. It will generate data and evidence about the health of Kenya's basic education system. Putting more premium on assessment for learning and assessment as learning (Chisholm \& Leyendecker, 2008; UNESCO IBE, 2013) will nurture and empower learners to engage more in the learning process and further develop their ethical behavior as espoused in the mission of the ongoing (2017) curriculum reform. The reform will usher policy alignment between curriculum content and assessment 
and reduce the academic load for learners as the basic education system sifts through, isolates, and focuses on those skills essential for the $21^{\text {st }}$ century characterized by the multiple pathway approach to education in the new curriculum.

Assessment information will have important implications on education policy, practice, and research to improve learning outcomes and graduate learners equipped with relevant knowledge, skills, values, and attitudes for sustainable development. Noteworthy is the use of portfolios to demonstrate learners' capabilities at different points in their academic journey. However, for the new assessment approach to succeed, teachers will need sustained professional support, mentoring, and coaching. Competent and motivated teachers will remain crucial for the successful implementation of educational assessment reforms.

\section{Discussion and Future Directions}

Kenya prides itself on a young and growing population, with over $80 \%$ of them under 35 years of age (NCPD, 2017 14 ). Most youth are in the basic education level and have immense potential to transform Kenya's economic fortunes. This transformation is possible if continuous improvement of the quality and relevance of skills young people possess when entering the job market is prioritized. Youth must have the right skillsets to be gainfully engaged. The demographic dividend must be harnessed to propel Kenya to higher levels. Targeted efforts must be expended on the quality and range of educational opportunities available to the youth. The next few years remain crucial in determining Kenya's socioeconomic and even political direction. A logical starting point is the ongoing curriculum reform processes whose main objective (and strength) is developing learners' competencies, skills, knowledge, values, and attitudes.

The situation in Kenya today is promising. There is a near gender-parity enrolment in basic education programs, demonstrating the government's commitment to improving educational access in the country. Free Primary Education, introduced in 2003, is the main driving force behind school attendance. The number of schools, number of pupils, and net enrolment in basic education (ECDE to $12^{\text {th }}$ grade) have grown steadily. Free Day Secondary Education was introduced in 2008, and capitation increased from KSh28bn $(\$ 308 \mathrm{~m})$ to KSh32bn (\$350m), representing 15\% of the national budget for the 2015/16 fiscal year. The government now shoulders the responsibility of paying examination fees for all candidates in the $8^{\text {th }}$ and $12^{\text {th }}$ grades. Heavy public spending on education (Jepkemei, 2017; Muricho \& Chang' ach, 2013) and the waiving of levies to learners demonstrate the government's commitment to building an accessible and effective education system. The huge investment should translate to increased enrolment rates in basic education and improved access and quality of education for all.

Basic educational outcomes in Kenya remain low. UNESCO (2012) and UWEZO (2016) reports affirm that many children are graduating without requisite skills for the world of work. About 39\% of women are illiterate or semi-illiterate after six years of schooling. An even bigger challenge is the scenario in which youth are being prepared for jobs that have not yet been created. The education system must operate in synchronization with demands from the ever-evolving labor market. The revised curricula address this gap by aligning learners' skills being developed to job-market requirements.

Emphasis (and concern) on learning outcomes is the impetus needed to ensure that curriculum and teaching quality reflects the government's efforts in improving access and

14 National Council of Population and Development. (NCPD, 2017). Youth Bulge in Kenya: A Blessing or Curse (Policy Brief No. 56). Nairobi: NCPD 
attendance if Kenya hopes to reap dividends of the bottom-heavy demographic bulge (NCPD, 2017). If done appropriately, it will reduce the dependency ratio - the percent of the nonworking-age population to working-age population - of $80.9 \%$ on the country's welfare system. With more youth in gainful employment, tax revenues will grow. Productivity will increase as well, especially when the emerging labor force is adequately prepared. To address these issues, inter-disciplinary and multi-sectoral approaches must be adopted to make educational content more relevant to future employment opportunities. To this end, discussions with the private sector are imperative. Undoubtedly also, reforms must align with the Constitution of Kenya (2010), Kenya's Vision 2030, and, on the international scene, Sustainable Development Goals, including goal Four and $21^{\text {st }}$-century skills, if learners have to meaningfully contribute to national development.

ICTs can and have been harnessed before to improve the quality of basic education and as a means to reach all learners with and without disabilities, those in marginalized regions and the vulnerable. Once the extensive electrification of over 22,000 primary schools is complete, the next logical step should be to connect the schools to the high-speed fiberoptic network. These infrastructure developments will pave the way to learning on the go anytime, anywhere, anyhow. We see the teacher increasingly playing a more facilitative role. How then do we expect the curriculum to look like then? What provisions need to be made in the curriculum reform right now to accommodate these novel ways of learning?

Curriculum implementation in the past has been rid with many challenges. The most critical one has been the number of teachers in the workforce. Boosting numbers of wellqualified, and motivated, teachers will remain high on the agenda for improving learning outcomes. In 2013, the student-teacher ratio in primary schools was 52 to 1 and 32 to 1 for secondary schools. To improve educational quality, the provision of more teachers is required to meet the UN recommended teacher-student ratio of one teacher for every 35 students. The import of this is the need to employ an additional 79,000 teachers, a move that requires strategic fiscal thinking, including the substantial expansion of the ministry's budget $-83 \%$ of MoEST's recurrent budget.

Close collaboration between educational institutions and the private sector should continue being forged and/or strengthened. More internships and service-learning field placements accompanied by incentives, such as tax rebates for collaborating private sector organizations, should be encouraged. Private enterprises should be encouraged to work directly with universities and other tertiary institutions to not only improve the quality of education and job readiness of new graduates but also to identify and nurture talent. Mentoring and coaching should be mainstreamed. These efforts address some of the funding crises many institutions of higher learning are currently facing.

The Kenyan education sector will continue to benefit from several comparative advantages, including improving educational access and strong government-and donorsupport. Education remains a game-changer in the lives of Kenyan children, the result being the production of self-reliant learners ready for the global market. Science, technology, and innovation must take center-stage to address the demand for mid-level skills. The government's flagship project of setting up technical training institutions in each region and constituency in the country will, hopefully, spur the county towards the achievement of Vision 2030.

Ominde Commission (1964), Mackay Report (1981), and other curricula reform efforts viewed education as a solution to unemployment by foregrounding talents and provision of technical and vocational skills. Current curriculum reform proposes multiple pathways to education and identification and nurturing of talents. 
The 8-4-4 system of education was doomed to fail in the absence of fully equipped science labs and workshops and trained teachers ready to use learner-centric pedagogy. a. Ongoing curriculum reform is premised on a true learner-centric pedagogy: learning activities promote learner participation, with the teacher as a guide.

Assessment reforms envisioned in the new curriculum pave the way to regional and international assessments (such as PISA-D, TIMMS, and PIRLS) (UNESCO, 2000). It is a move away from norm-referenced to criterion-referenced testing that helps generate information about learner understandings, skills, competencies, or behavior that can be expected of a person with a given score. Constructivist approaches undergird Criterionreferenced assessment to learning, which determines learners' understanding, not just their knowledge in each learning area and their ability to apply new knowledge in various situations (Fenstermacher and Soltis, 2015). Learners are expected to not only demonstrate relevant generic skills but develop their abilities for self-reflection and self-assessment about their learning. That also means that teacher-centric approaches must give way to learnerfriendly pedagogies. Learners will increasingly take charge of their learning that goes beyond memorization of facts and regurgitation in the classroom and during exams (Pontefract \& Hardman, 2005). Such an approach brings to the center of teaching and learning processes that tap into children's interests, experiences, and needs and automatically tilts in favor of developing, in learners, higher-order thinking skills, critical analysis, and reflection (Kellagan \& Greeney, 2005).

Results from international learning assessments play a critical role in the monitoring of learning outcomes, education quality and ensure accountability. They inform education policymaking and promote prudent resource allocation and use. From a motivational perspective, a move away from high stakes examinations can ease pressure on teachers about their job security and redirect their efforts to genuine career growth and development. This, in turn, could shift attention to teacher quality and standards hinged on continual improvement with important implications on the quality of teaching and learning practices, content choice, and education quality in general (Kellagan \& Greeney, 2005; Somerset, 2011).

Teachers' capacity to handle labor demanding and time-consuming practical lessons remains an ever-present challenge given many of the teachers are themselves products of theory-based and teacher-centered teacher training programs. Additionally, implementation of a learner-centered pedagogy is an almost insurmountable task within a resource-poor context led by poorly remunerated and often demotivated teachers. Curriculum change requires teacher re-tooling, including training on novel assessment techniques, diversification and adaptation of the curriculum to local needs (Balarin \& Benavides, 2010), accommodation of indigenous knowledge in the classroom, and use of gender-sensitive pedagogies and instructional materials that provide a more positive image of women and girls and their role in society (Naseem, 2010). Ample evidence indicates that children are more motivated and better positioned to learn if their background knowledge and experiences are incorporated into their learning environments. Indigenization of the curriculum (Chisholm \& Leyendecker, 2008) will thus be imperative.

Past curriculum reforms have been demoralizing because of their failure to meaningfully address systemic issues dogging the education system and minimize wastage of time, energy, and resources. A case in point is the mismatch between student qualifications and current market demand needs. In the same breath, the structural challenges provide an opportunity for system-wide reforms and an overhaul of the whole education system, especially in the governance, leadership, accountability, ownership, funding architecture, institutional capacity, and monitoring and evaluation domains (Psacharapoulos, 1988), hence 
the reform currently (2017) underway. Otherwise, and in Jepkemei's (2017) words:

We can get the structure we want, but what does it mean if our children remain "unbuilt"? What is the point of setting a beautiful dinner table if the food is not nourishing? We need to focus on what matters. Let's get the curriculum and accountability right. The structure will fall in place. So, is reform cheap? No, it isn't. Neither is an ineffective, unaccountable education system.

The politicization of education has been one of the major challenges in education in Kenya and, in part, contributed to the failure of past curricular reviews and reforms. The challenge is further complicated by politicians ignorant of the wherewithal of a successful curriculum reform process that considers issues such as teacher and student factors, school ethos and management, and physical resources. Heneveld and Craig (1996) and Rogan and Grayson (2003) posit that successful implementation of curriculum reforms depend on the extent to which policymakers and planners consider the whole school context and the current level of curriculum and classroom practice, and capacity to support reform.

- Ongoing curriculum reforms should address the language of instruction and other issues surrounding indigenous knowledge, cultural expression, and identities in transformative and empowering ways (Brock-Utne, 2001) and maintenance of cultural heritage.

- The government should secure inter-disciplinary and multi-sectoral engagements in providing basic education and eliminating the silo approach to education service delivery options by both state and non-state actors.

- National values, community service learning, and physical education should link what happens in the classroom to the real world - a fit-for-purpose approach, if you may. Jepkemei (2017) notes that the curriculum has to be both challenging and connected to "real-world" applications such as service and internship. It is the only way to make the curriculum relevant.

- The new curriculum should be inclusive and guarantee achievement for/of/by all learners, including those living with disabilities. Let no child be left behind. That means targeted efforts should be made towards children with special needs and the marginalized and vulnerable children in poorly resourced arid and semi-arid regions of the country.

- The government should address other key factors that affect education quality by stemming out corruption and plugging holes for siphoning public funds. Curriculum reforms should not be cosmetic but result in real change for graduates to look beyond white-collar employment to the creation of their jobs and the freedom that comes with it.

\section{Conclusion}

Several curricular reforms in Kenya have happened over time in response to the labor market's needs and to align curricula with local and international legal instruments (such as the Constitution of Kenya (2010 and Sustainable Development Goals) that shape education.

Arguably, the Kenyan curriculum is becoming more inclusive, competence-based, and practice-oriented to nurture $21^{\text {st }}$-century skills. Pedagogical approaches are becoming more learner-centered with equal educational opportunity for all emphasized. More value is being placed on assessment for and as learning than on an assessment of learning. Curricula reform goals and objectives revolve around Kenya's demographic and legislative realities against the backdrop of systemic problems (such as huge class sizes and teacher absenteeism), which 
jeopardize the achievement of expected learning outcomes.

Contextualizing education to regional differences affirms democracy in education towards the devolution of education functions and services. It answers questions of who decides what is worthwhile to know and experience in order for learners to reach greater potential and develop into responsible human beings capable of contributing meaningfully to sustainable development. It combines centralized and grassroots reform efforts to yield excellence, equity, and genuine human growth and assures a bright future for Kenya's children.

\section{Recommendations}

Based on the findings reported in this paper, the following recommendations are made:

1. Stakeholder participation in curriculum reform: The widest extent of education stakeholders should be involved in curriculum reform. Teacher inclusion in the design, development, and implementation of the new curriculum should be prioritized. After all, teachers are the most important change agent on the education work floor.

2. Strategic implementation of the reformed curriculum: Implementation of the new curriculum should be well-planned and structured to yield expected learning outcomes. The reforms must be communicated clearly and efficiently to all actors involved in implementation at different levels to avoid irregularities, confusion, and resistance from teachers as has characterized previous rollouts. Resistance to reforms should be viewed as critical to improving education and futureproofing it. Teachers should be properly oriented and re-skilled, and essential learning and teaching materials availed in all schools. A robust implementation plan ensures that necessary conditions and an enabling environment are guaranteed and made available for teachers and schools.

3. Synchronization of basic education and teacher education curriculum reform: Pre- and in-service teacher education programs should be reformed simultaneously with basic education curriculum reforms to better meet the demands of competencybased education.

4. Curriculum policy review and/or alignment: Basic education curriculum policies on content, pedagogy, and assessment should be reviewed and/or aligned to ensure effective and efficient curriculum implementation.

5. Implementation of alternative assessment methods to track learner achievement: Assessment for learning (formative) and assessment as learning should be prioritized to empower learners to monitor their learning progress and growth and for setting new academic goals. Less emphasis should be placed on the assessment of learning (summative) to eliminate rote learning and nurture mastery learning in which learners demonstrate what they know and can do. This will be a double-edged strategy to curb examination-based education characterized by cut-throat competition, cramming, and regurgitation of content.

\section{References}

Abagi, O., \& Olweya, J. (1999). Educational reform in Kenya for the next decade. Institute of Policy Analysis and Research.

Achola, P. P. W., \& Pillai, V. K. (2000). Challenges of primary education in developing countries: Insights from Kenya (1st ed.). Routledge.

Amukowa, W., Gunga, S., \&Vihenda, C. (May 2013). Can education system be repaired? 
Ideological dearth in Kenya's educational practice and its implications for reforms in the education sector. Journal of Education and Social Research, 3(2), $213-229$.

Amutabi, M. (2003a). The 8-4-4 system of education. International Journal of Educational Development, 23, 127-144.

Amutabi, M. N. (2003b). Political interference in the running of education in postindependence Kenya: a critical retrospection. International Journal of Educational Development, 23(2), 127-144. https://doi.org/10.1016/s0738-0593(01)00055-4

Balarin, M., \& Benavides, M. (2010). Curriculum reform and the displacement of knowledge in Peruvian rural secondary schools: Exploring the unintended local consequences of global education policies. Compare: A Journal of Comparative and International Education, 40 (3), 311 - 325. https://doi.org/10.1080/03057920903374440

Bennett, R. E. (2011). Formative assessment: a critical review. Assessment in Education: Principles, Policy \& Practice, 18(1), 5-25. https://doi.org/10.1080/0969594x.2010.513678

Bogonko, S. N. (1992). A history of modern education in Kenya (1895-1991). Evans Brothers (Kenya).

Braslavsky, C. (2003). The curriculum. Geneva: UNESCO IBE.

Brock-Utne, B. (2001). Education for all - in whose language? Oxford Review of Education, 27(1), 115-134. https://doi.org/10.1080/03054980125577

Chisholm, L., \& Leyendecker, R. (2008). Curriculum reform in post-1990s sub-Saharan Africa. International Journal of Educational Development, 28(2), 195-205. https://doi.org/10.1016/j.ijedudev.2007.04.003

CCSSO. (2005). Glossary of assessment terms and acronyms used in assessing special education students ( $2^{\text {nd }}$ ed.). Council of Chief State School Officers.

Desouza, H. (1987). Kenya education in its context. Vantage Press.

Dunn, K. E., \& Mulvenon, S. (2009). A critical review of research on formative assessment: Limited scientific evidence of the impact of formative assessment in education. Practical Assessment, Research and Evaluation, 14(7), 1-11.

Eisemon, T. O. (1988). Benefiting from basic education, school quality, and functional literacy in Kenya (comparative and international education series) (1 st ed.). Pergamon Pr.

Eshiwani, G. (1992). Education in Kenya since independence. East African Educational Publishers.

Fenstermacher, G., \& Soltis, J. (2015). Approaches to teaching. Teachers College, Columbia University Press.

Greaney, V., \& Kellaghan, T. (2008). Assessing national achievement levels in education: National Assessments of Educational Achievement (Vol 1). The World Bank.

Heneveld, W., \& Craig, H. (1996). Schools count: World Bank project designs and the quality of primary education in sub-saharan Africa (World Bank technical paper). World Bank.

Illich, I. (1970). Deschooling society. Allen and Unwin.

Jepkemei, E. (5 ${ }^{\text {th }}$ April, 2017). Curriculum Reform: Is it worth the trouble? Retrieved from https://www.standardmedia.co.ke/article/2001235123/curriculum-reform-is-itworth-the-trouble

Kaviti, L. (2018). The new curriculum of education in Kenya: a linguistic and education paradigm shift. Journal of Humanities and Social Science, 2(23), 84-95.

Kellaghan, T., \& Greaney, V. (2005). Monitoring performance: Assessments and examinations. In A. M. Verspoor (Ed.). The challenge of learning: Improving the quality of basic education in Sub-Saharan Africa (pp. 271-292). Paris: Association for the 
Development of Education in Africa.

Kenya Institute of Curriculum Development (KICD). (2017a). Basic education curriculum framework (BECF): Nurturing every learner's potential - Engaged, empowered and ethical citizen. (pp. 1 - 158). Kenya Institute of Curriculum Development. https://kicd.ac.ke/curriculum-reform/basic-education-curriculum-framework/

Kenya Institute of Curriculum Development (KICD). (2017b). CBC materials: Popular slides on $C B C-$ Series 4. Kenya Institute of Curriculum Development.

https://kicd.ac.ke/cbc-materials/popular-slides-on-cbc/

Kerre, B. (1997). The technical and vocational education for rural development: The case of Kenya. International Project on Technical and Vocational Education. UNEVOC.

King, K., \& McGrath, S. (2002) Globalization, Enterprise and Knowledge Education, Training and Development in Africa. Symposium, Oxford.

Kivuva, A. (2005). Secondary education reform in Kenya: The quest for quality, relevancy, and equality. URL: http://www.ginie.org/cstudies/africa/es-africa.htm

Lamm, Z. (n.d). Ideologies and educational thought. Hebrew University of Jerusalem.

Looney, J. (2011). Integrating formative and summative assessment: Progress toward a seamless system? (OECD Education Working Papers No. 58). Organisation for Economic Cooperation and Development. https://doi.org/10.1787/19939019

Mackatiani, C., Imbovah, M., Imbova, N., \& Gakunga, D. (2016). Development of education in Kenya: Influence of the political factors beyond 2015 MGDs. Journal of Education and Practice, 7(1 1), 55-60.

Makori. A. (2005). The Kenya's educational policy: Exploring some of the major impediments to redesigning pedagogy [Paper presentation]. 2005 International Conference at Nanyang Technological University, Singapore.

Meighan, R., \&Siraj-Blatchford, I. (1997). A sociology of education. Cassell.

MoEST. (2012). Taskforce on re-alignment of the education sector to the Constitution of Kenya 2010: Towards a globally competitive quality education for sustainable development (Report of the Task Force). Ministry of Education, Science, and Technology, Republic of Kenya.

MoEST. (2014). Basic Education Statistical Booklet. Ministry of Education, Science, and Technology, Republic of Kenya.

MoEST. (2015). National curriculum policy. Ministry of Education, Science, and Technology, Republic of Kenya.

Muya, W. (2000). Great expectations as new system seems likely. Daily Nation. http://www.nationaudio.com/News/DailyNation/2202000/News59.html

Muricho, P. W., \& Chang' ach, J. K. (2013). Education reforms in Kenya for innovation. International Journal of Humanities and Social Sciences, 3(9), 123 - 145.

Naseem, M. A. (2010). Education and gendered citizenship in Pakistan. Palgrave.

NASMLA. (2010). The Kenya National Examination Council.

NCEOP. (1976). Report of the National Committee on Educational Objectives and Policies. National Committee on Educational Objectives and Policies.

National Council of Population and Development [NCPD]. (2017). Touth Bulge in Kenya: A Blessing or Curse (Policy Brief No. 56). Nairobi: NCPD.

Njeng' ere, D., \& Lili, J. (2017). The why, what and how of competency-based curriculum reforms: The Kenyan experience in UNESCO's Series on Current and Critical Issues in Curriculum, Learning and Assessment. Online available:

https://unesdoc.unesco.org/ark:/48223/pfo000250431 
Njeng' ere, D. (2014). The role of curriculum in fostering national cohesion and integration: Opportunities and challenges (IBE Working Papers on Curriculum Issues No. 11). UNESCO.

Ogutu, D. M. (2017). Education system change: perspectives from Kenya. Brookings. https://www.brookings.edu/opinions/education-system-change-perspectives-fromkenya

Ojiambo, P. (2009). Quality of education and its role in national development: A case study of Kenya's educational reforms. Kenya Studies Review, 1(1), 133-149.

Oketch, M., \& Rolleston, C. (2007). Policies on free primary and secondary education in East Africa: Retrospect and prospect. Review of Research in Education, 31(1),131-158. https://doi.org/10.3102/0091732X07300046131

Oluoch, G. (1982). Essentials of curriculum development. Longhorn Publishers.

Ominde, S. (1964). Kenya Education Commission Report. Kenya Education Commission.

Onsomu, E., Nzomo, J., \& Obiero, C. (2005). The SACMEQ II Project in Kenya: A study of the conditions of schooling and the quality of education. SACMEQ.

Otiende, E., Wamahiu, P., \& Karagan, M. (1992). Education and development in Kenya: A historical perspective. Oxford University Press.

Owino, C. (1997). Vocational education in primary schools in Kenya and Tanzania: A comparative study with special reference to Kenya [Unpublished MA dissertation]. Moi University.

Omukubi, N. (2014). Challenges of education in Kenya. Jamhuri Magazine.

PAL Network. (2020). ICAN: International Common Assessment of Numeracy. Background, features and large-scale implementation. People's Action for Learning Network.

Piper, B. \& Schroeder, L. \& Trudell, B. (2015). Oral reading fluency and comprehension in Kenya: reading acquisition in a multilingual environment: Fluency and Comprehension in Kenya. Journal of Research in Reading. 39. 10.1111/14679817.12052.

Piper, B., \& Zuilkowski, S. (2015). Teacher coaching in Kenya: Examining instructional support in public and nonformal schools. Teaching and Teacher Education. 47, 173183. https://doi.org/10.1016/j.tate.2015.01.001

Pontefract, C., \& Hardman, F. The discourse of classroom interaction in Kenyan primary schools. Comparative education, 41(1), 87-106.

https://doi.org/10.1080/03050060500073264

Province of Manitoba. (2006). Rethinking classroom assessment with purpose in mind: Assessment for learning, assessment as learning, assessment of learning. Manitoba Education, Citizenship, and Youth, School Programs Division.

Psacharopoulos, G., (1988). Education and development: A review. World Bank.

Republic of Kenya. (1964). Kenya Education Commission Report, Part I. Kenya Education Commission.

Republic of Kenya. (1976). The National Committee on Educational Objectives and Policies (Gachathi Report). NCEOP.

Republic of Kenya. (1981). Second University: Report of Presidential Working Party (Mackay Report). Nairobi: Government Printer.

Republic of Kenya. (1983). Presidential Committee on Unemployment (1982/1983) (Wanjigi Report). Presidential Committee on Unemployment.

Republic of Kenya. (2005). Sessional Paper No. 1. Ministry of Education, Science, and Technology.

Republic of Kenya (2012). "Education reforms - recommendations” Ministry of Education, 
Science, and Technology.

www.education.go.ke/ShowPage.aspx? department $=1 \& i d=1164$

Rharade, A. (1997). Educational reform in Kenya. Prospects, 27(1). UNESCO.

Rizvi, F. \& Lingard, B. (2010). Globalizing education policy. Routledge.

Sifuna, D. (1990). Development of education in Africa: The Kenyan experience. Initiatives Publishers.

Sifuna, D., \& Otiende, J. E. (1995). Introduction to history of education. University of Nairobi Press.

Simiyu, J. W. (1990). Vocational and technical education and training in Kenya: Case studies of two exemplary youth polytechnics [Unpublished MA dissertation]. University of McGill, Montreal.

Simiyu, J. W. (2001). Factors which influence the teaching of technical and vocational subjects in primary schools in UasinGishu district. [Unpublished MA dissertation]. Moi University.

Somerset, A. (2011). Strengthening educational quality in developing countries: The role of national examinations and international assessment systems. Compare: A Journal of Comparative and International Education 41(1), 141-144. https://doi.org/10.1080/03057925.2011.534851

Stanfield, J. (2005). Kenya's forgotten independent school movement. Blackwell Publishing. Trudell, B. (2012). Of gateways and gatekeepers: Language, education and mobility in francophone Africa. International Journal of Educational Development, 32(3), 368-375. https://doi.org/10.1016/j.ijedudev.2011.11.007

UNESCO. (2000). Dakar Framework for Action: Education for All. Meeting Our Collective Commitments. World Forum on Education, Dakar, Senegal, 26 - 28 April 2000, UNESCO, Paris.

UNESCO. (2012). EFA Global Monitoring Report on Youth and Skills: Putting Education to Work. Available at: https://unesdoc.unesco.org/ark:/48223/pfo000218003

UNESCO IBE. (2013). Glossary of curriculum terminology. UNESCO International Bureau of Education.

Uwezo. (2012). Are our Children Learning? http:/ / www.uwezo.net/wpcontent/uploads/2014/05/Kenya-Report-2012-WebFinalUpdate.pdf

Uwezo. (2014). Are our Children Learning? http://www.uwezo.net/wpcontent/uploads/2016/05/05-16-Kenya-small-size.pdf

Uwezo. (2015). Are our Children Learning? http://www.uwezo.net/wpcontent/uploads/2016/12/UwezoKenya2015ALAReport-FINAL-EN-web.pdf

Uwezo. (2016). Are our Children Learning? http://www.uwezo.net/wpcontent/uploads/2016/12/UwezoKenya2015ALAReport-FINAL-EN-web.pdf

Waiganjo, K. (2017, March 25). We are raising bookworms who are socially, emotionally stunted. The Standard. https://www.standardmedia.co.ke/kamothowaiganjo/article/2001233919/we-are-raising-bookworms-who-are-sociallyemotionally-stunted

Wananga, P., Ogle, A., \& Wambua, R. (2010). Report on monitoring of learner achievement for class 3 in literacy and numeracy. Kenya National Examinations Council.

Wanjala, E. (2017, December 25). New 2-6-3-3-3 curriculum: How different is it from the 8-4-4 system? The Star. https://www.the-star.co.ke/news/2017-12-25-new-2-6-3-3-3curriculum-how-different-is-it-from-the-8-4-4-system

Wanjohi, A. M. (2018, April 15). Critical Review of 8-4-4 Education System in Kenya. Schools Net Kenya. https://www.schoolsnetkenya.com/critical-review-of-8-4-4-education- 


\section{system-in-kenya}

Wanjohi, A. M. (2011). Development of education system in Kenya since independence. KENPRO Online Papers Portal. www.kenpro.org/papers.

World Bank. (2005). Expanding opportunities and building competencies for young people: A new agenda for secondary education. World Bank.

World Bank. (2018). World development report: Learning to realize education's promise. World Bank.

Wycliffe, A., Samson, G. O., \& Ayuya, V. C. (2013). Can education system be repaired? Ideological dearth in Kenya's educational practice and its implications for reforms in the education sector. Journal of Educational and Social Research, 3(2), 213-229.

https://doi.org/10.5901/jesr.2013.v3n2p213

\section{About the Authors}

Justus O. Inyega holds a PhD (Science Education) and Postgraduate Certificate in multidisciplinary qualitative research from the University of Georgia, USA, M. Ed. (Science Education), University of Leeds, UK, M. Ed (Admin.) and B. Ed (Primary Education Option) from Kenyatta University, Kenya. In addition, Inyega is also holder of Postgraduate Certificate in Chemical Education (Hiroshima University), and Certificate in Project Cycle Management (JICA, Tokyo). Inyega is an Associate Professor in the Department of Educational Communication and Technology, School of Education, College of Education and External Studies, University of Nairobi. Inyega is also the Director, Centre for Pedagogy and Andragogy (CEPA), which in-services University lecturers on teaching methodologies in higher education. Inyega has a wide range of teaching experience at all levels of education, within Kenya and in the United States, for over 30 years, 19 years of which in high schools and tertiary teacher training colleges and polytechnic, and 17 years in university teaching, research, consultancy and community work. Inyega has also experience in management of research-based projects in Kenya. He has successfully worked with University of Nairobi preservice teachers in a USAID-sponsored project on early grade reading as the Principal Investigator. Inyega has also been a Co-principal investigator in the Cross-age Peer Tutoring in the Teaching of Reading in Primary Schools in Kenya Project that was funded by the Economic and Social Research Council (ESRC) through University of York, United Kingdom.

Adeela Arshad-Ayaz is an Associate Professor at the Department of Education, Concordia University. She received her Ph.D. in Comparative and International Education and Sociology of Education from McGill University. Prior to joining Concordia University, she held a tenure-track position at the Faculty of Education, University of Regina. Dr. Arshad-Ayaz is a postcolonial, transnational feminist and critical theorist with interest and expertise in the sociology of technology, citizenship/civic participation and engagement, anti-extremism and anti-radicalization education, globalization, international development, and cultural pluralism. Her published work explores education policies related to educational technology in Western and developing countries such as Kenya, Pakistan, Indonesia, etc. She has also published on the impact of globalization on educational policy and the impact of social media on youth's civic engagement and issues related to diversity in culturally pluralist societies. Her ongoing research includes (FQRSC, SSHRC, and Security Canada) funded projects on social media for civic engagement and participation, social media and cultural pluralism, and the dark side of social media: hate speech in online environments. She is the Co-convenor and co-chair for the Annual International Symposium on Teaching about Extremism, Terror, and Trauma (http://www.tett.ca/). She has also served as the Principal 
for Loyola College for Diversity and Sustainability and Co-managing Editor of the Journal of Contemporary Issues in Education (JCIE). Her research has been featured in leading newspapers, including Le Devoir.

M. Ayaz Naseem is a Professor of Education at Concordia University, Montreal. He holds a Ph.D. in Comparative and International Education from McGill University, Montreal. Prior to joining Concordia University, he taught at the departments of International Relations and Defense and Strategic Studies at the Quaid-i-Azam University, Islamabad, Pakistan. His research interests are situated on the cross section of peace education, social media as space for peace education, teaching about extremism, terror, and radicalization, feminist theory and philosophy, post-structuralism, and citizenship education. In 2013-14, he held the First Georg Arnhold Research Professorship on Educating for Sustainable Peace at Georg Eckert Institute in Braunschweig, Germany. He has published widely including six books and over fifty articles and book chapters. His co-authored book Scientism and Education was awarded the prestigious American Educational Studies Association Critics Choice Award 2008. His book Education and Gendered Citizenship in Pakistan (Palgrave-McMillan, 2010) was a finalist for the CIES Jackie Kirk Outstanding Book Award. It was also nominated for the American Institute of Pakistan Studies Book Award. He has guest-edited special issues of the Journal of Educational Media, Memory, and Society (JEMMS) and Journal of Current Issues in Education. His research has been funded by the Social Sciences and Humanities Research Council, FRQ-SC, Public Security Canada, Humboldt Foundation (Germany), Georg Arnhold Foundation (Germany), Quaid i Azam University (Pakistan).

Evans $W$. Mahaya is a PhD student/research assistant at the University of Nairobi; College of Education and Eternal Studies. His doctoral program is domiciled in the Department of Educational Communication and Technology. He holds a Master of Arts degree Education from the University of Georgia (USA) and Bachelor of Education degree from Kenyatta University (Kenya). Prior to joining Graduate School, he taught Chemistry and Mathematics at High School and lectured part-time at Kisii University (Kenya). Over the last 10 years, he has been involved in Research and Consultancy activities for donor-funded projects in Kenya (by USAID, DFID, ESRC, CIFF, TrustAfrica, CODE) focusing on educational research, monitoring and evaluation, teacher training and capacity-building, classroom teacher support, supervision and material development. He has worked with research organizations such as RTI International, AGA Khan Foundation, Management Systems International, Educational Development Trust, Genesis Analytics and University of Nairobi to advance their research agenda. His research interests include; technology integration in teaching and learning, blended-learning in higher education, assessment of learning and classroom teacher support and supervision.

Dalia Elsayed is a third year PhD student in the Education Department at Concordia University. She received her Bachelor of Science from Georgetown University School of Foreign Service in Qatar with a focus on Middle Eastern and African studies. Dalia completed her master's degree At Qatar University's Gulf Studies Program where her research focused on power structures under Sharia law, non-western forms of feminist discourses, and Islamic feminist resistance in Iran and Saudi Arabia. Currently, Dalia's PhD research focuses on race, critical theory, intersectionality, and feminist epistemology. Her scholarship seeks to understand Blackness in a global perspective focusing particularly on the experiences of the Black African in the diaspora. In doing so, Dalia is interested in understanding the different narratives and frameworks that contribute to the formation and the articulation of Black identity/identities globally. 